\title{
EDITORIAL
}

\section{The respiratory muscles: cellular and molecular physiology}

\author{
M. Decramer*, M. Aubier**
}

The respiratory muscles have been studied extensively during the last $20 \mathrm{yrs}$. This interest was triggered predominantly by the observation made by Roussos and MACKLEM [1] that the respiratory muscles, like all other skeletal muscles, may fatigue. Subsequent research critically examined the significance of inspiratory muscle fatigue in clinical pulmonary medicine. The conclusion of this research was largely that inspiratory muscle fatigue was rarely, if ever, present [2, 3]. Respiratory muscle fatigue appeared to be effectively avoided by reduction of the duration of inspiration whenever the limits of respiratory muscle performance were approached [4]. This reduction in the duration of inspiration leads to an inappropriately small tidal volume, and, hence, to alveolar hypoventilation and consequent hypercapnia $[4,5]$. Inspiratory muscle fatigue, therefore, appeared to occur only in exceptional circumstances, such as cardiogenic [6] or septic shock [7] and weaning from mechanical ventilation [8]. The limits of respiratory muscle performance are determined by respiratory muscle force and endurance capacity. At present, there are few data on the clinical significance of respiratory muscle endurance. There are, however, abundant data on respiratory muscle weakness.

Indeed, the clinical significance of respiratory muscle weakness is now clearly established, not only conceptually (see above), but also through empirical observation. Although there are, without question, other circumstances in which it is important, it has been most extensively studied in patients with chronic obstructive pulmonary disease (COPD). The present Editorial, therefore, will focus primarily on COPD. Inspiratory muscle weakness was shown to be related to dyspnoea [9], fatigue, and exercise limitation in COPD patients [10]. Expiratory muscle weakness was shown to be related to cough efficiency $[11,12]$. In addition, inspiratory muscle weakness is an important determinant of the development of hypercapnic respiratory failure [13]. As hypercapnic respiratory failure is the most important cause of death in COPD [14], inspiratory muscle weakness is, therefore, also expected to be related to mortality in these patients. At least two observations support the presence of such a relationship. Indeed, DECRAMER et al. [15] demonstrated that survival was severely reduced in patients with COPD and steroidinduced myopathy in comparison to control COPD patients, despite the fact that they had the same degree of airflow obstruction and hyperinflation, the known major

Correspondence: M. Decramer, Respiratory Division, University Hospitals, Herestraat 49, B-3000 Leuven, Belgium. *Respiratory Muscle Research Unit, Laboratory of Pneumology, Katholieke Universiteit Leuven, Leuven, Belgium. **Hôpital Bichat, Paris, France. determinants of survival in COPD. Moreover, GRAY-DONALD et al. [16], in a cohort study on 348 COPD patients, demonstrated that, in hospitalized COPD patients, maximal inspiratory pressure $(P I, \max )$ was an independent determinant of survival, besides hypercapnia, body mass index and transfer factor.

There are numerous factors potentially contributing to respiratory muscle weakness in COPD patients. Inspiratory muscle weakness may be related to hyperinflation, which puts the inspiratory muscles at a less advantageous position of their length-tension curve [17], and causes geometrical alterations in the inspiratory muscles. Both factors curtail the force-generating capacity of the respiratory muscles. Moreover, hyperinflation increases the dimensions of the rib cage, such that the muscles at the periphery have to generate a greater tension to develop the same change in pleural pressure in order to produce the same tidal volume [18]. Although adaptations to chronic hyperinflation most probably occur, the overall effect of hyperinflation on the inspiratory musculature is likely to be detrimental [19]. This is confirmed by the observation that volume reduction surgery, which in essence reduces hyperinflation, improves inspiratory muscle function [18, 20-22].

In addition, generalized muscle weakness is present in COPD patients [23]. Both the inspiratory and expiratory muscles partake in this muscle weakness. There are several causes of this generalized muscle weakness. They include: malnutrition [24]; cardiac failure [25, 26]; hypoxaemia; hypercapnia [27]; steroid treatment [28, 29]; electrolyte disturbances, such as hypomagnesaemia [30]; and hypophosphataemia [31] etc.

Clearly, the peripheral muscles also participate in this generalized muscle weakness, and a number of studies have recently underlined the significance of peripheral muscle weakness in COPD patients. Three studies have demonstrated a relationship between peripheral muscle force and exercise capacity in COPD patients, suggesting that exercise limitation is frequently associated with peripheral muscle dysfunction [10, 32, 33]. Two other studies have shown that peripheral muscle training resulted in beneficial effects. In the first study, strength training was applied. It resulted in improvements in muscle force and quality of life [34]. In the second study, low intensity endurance training was performed. The beneficial effects observed were: reductions in dyspnoea; and reduced ventilatory requirements [35]. Although, conceptually, it would be expected that, primarily, endurance training would be beneficial, at present it remains unclear whether strength or endurance training results in the greatest benefit to COPD patients. The mechanism of peripheral muscle dysfunction is likely 
to be related to deconditioning combined with the abovementioned factors causing generalized muscle weakness.

Most studies on respiratory and peripheral muscle function so far, have been classical clinical and physiological studies. Although these studies have contributed greatly to our understanding of the role of the respiratory muscles in clinical medicine, new powerful tools have now become available. These make it possible to obtain better insight into the mechanism of muscle derangement, and provide a potential rational basis for the treatment of respiratory and peripheral muscle dysfunction. They are, in essence, techniques used in the study of cell and molecular biology. Active lines of research in this field include the damage caused to the diaphragm by oxygen free radicals [36, 37], and by nitric oxide production [38]. The series, "Cell Biology of the Respiratory Muscles", gives an overview of what is currently to be expected of these techniques and represents the contents of an Assembly Symposium held by the Clinical Physiology Assembly at the European Respiratory Society (ERS) annual meeting in Stockholm, 1996.

Four outstanding contributions by the best scientists in this field will update the reader with a state-of-theart overview. The first contribution by SIECK and PRAKASH [39] studied myosin heavy chain expression in single diaphragm fibres and its relationship to cross-bridge kinetics. This study improves insight into the relationship between contractile properties and myosin isoform expression.

The second paper by GEA [40] gives an overview of the regulation of myosin heavy chain expression in the respiratory muscles. Many of the factors detrimentally affecting respiratory and peripheral muscle function cited above, exert their effect through an influence on myosin heavy chain expression. Training appears to promote expression of slow myosin, thus improving the endurance capacity of the muscles. If the factors regulating myosin heavy chain expression were clearly understood, great potential to improve respiratory muscle function would be likely to be available. COPD patients would probably benefit from such potential.

AUBIER [41] studied the regulation of calcium-adenosine triphosphatase (Ca-ATPase) activity in the respiratory muscles. This is another basic process with significant effects on muscle function and undergoing major alteration in circumstances relevant to clinical pulmonary medicine.

Finally, in an overview, Petrof [42] summarizes the current potential for gene therapy to the respiratory muscles. The method employed is adenovirus-mediated gene transfer. This therapy is, without question, still associated with significant problems, such as destructive immune responses and expression of adenoviral gene products, both causing damage to muscle fibres and curtailing the muscle's force-generating capacity. Nevertheless, it unquestionably holds promise that in the future it will allow treatment of conditions such as genetic muscle diseases that were hitherto fatal.

Acknowledgements: The authors' studies were supported by the "Fonds voor Wetenschappelijk OnderzoekVlaanderen".

\section{References}

1. Roussos C, Macklem PT. Diaphragmatic fatigue in man. J Appl Physiol: Respirat Environ Exercise Physiol 1977; 43: 189-197.

2. Rochester DF. The diaphragm in COPD: better than expected, but not good enough. N Engl J Med 1991; 325: 961-962.

3. Rochester DF. Respiratory muscle failure and respiratory failure. Semin Respir Med 1992; 13: 7-13.

4. Aubier M, Murciano D, Fournier M, Milic-Emili J, Pariente R, Derenne JP. Central respiratory drive in acute respiratory failure of patients with chronic obstructive pulmonary disease. Am Rev Respir Dis 1980; 122: 191-199.

5. Sorli J, Grassino A, Lorange G, Milic Emili J. Control of breathing in patients with chronic obstructive lung disease. Clin Sci Mol Med 1978; 54: 295-304.

6. Aubier M, Trippenbach T, Roussos C. Respiratory muscle fatigue during cardiogenic shock. J Appl Physiol: Respirat Environ Exercise Physiol 1981; 51: 499-508.

7. Hussain SNA, Simkus G, Roussos C. Respiratory muscle fatigue: a cause of ventilatory failure in septic shock. J Appl Physiol: Respirat Environ Exercise Physiol 1985; 58: 2033-2040.

8. Cohen C, Zagelbaum G, Gross D, Roussos C, Macklem PT. Clinical manifestations of inspiratory muscle fatigue. Am J Med 1982; 73: 308-316.

9. Killian KJ, Jones NL. Respiratory muscles and dyspnea. Clin Chest Med 1988; 9: 237-248.

10. Gosselink R, Troosters T, Decramer M. Peripheral muscle weakness contributes to exercise limitation in COPD. Am J Respir Crit Care Med 1996; 153: 976-980.

11. Estenne M, Knoop C, Vanvaerenbergh J, Heilporn A, De Troyer A. The effect of pectoralis muscle training in tetraplegic subjects. Am Rev Respir Dis 1989; 139: $1218-1222$.

12. Arora NS, Gal TJ. Cough dynamics during progressive expiratory muscle weakness in healthy curarized subjects. J Appl Physiol: Respirat Environ Exercise Physiol 1981; 51: 494-498.

13. Begin P, Grassino A. Inspiratory muscle dysfunction and chronic hypercapnia in chronic obstructive pulmonary disease. Am Rev Respir Dis 1991; 143: 905-912.

14. Zielinski J, MacNee W, Wedzicha JA, et al. Causes of death in patients with COPD and chronic respiratory failure. Monaldi Arch Chest Dis 1997; 52: 43-47.

15. Decramer M, de Bock V, Dom R. Functional and histologic picture of steroid-induced myopathy in chronic obstructive pulmonary disease. Am J Respir Crit Care Med 1996; 153: 1958-1964.

16. Gray-Donald K, Gibbons L, Shapiro SH, Macklem PT, Martin JG. Nutritional status and mortality in chronic obstructive pulmonary disease. Am J Respir Crit Care Med 1996; 153: 961-966.

17. Decramer M. Effects of hyperinflation on the respiratory muscles. Eur Respir J 1989; 2: 299-302.

18. Decramer M. Hyperinflation and respiratory muscle interaction. Eur Respir J 1997; 10: 934-941.

19. Similowski T, Yan S, Gauthier AP, Macklem PT, Bellemare F. Contractile properties of the human diaphragm during chronic hyperinflation. N Engl J Med 1991; 325: 917-923.

20. Teschler H, Farhat A, Stamatis G, Costabel U, Konietzko N. Efficiency of the respiratory muscle pump pre- and post-lung volume reduction surgery. Am J Respir Crit Care Med 1996; 153: A788. 
21. Leyensen V, Criner GJ, Furukawa S, et al. Effect of lung volume reduction surgery on diaphragm strength in severe hyperinflated COPD patients. Am J Respir Crit Care Med 1996; 153: A788.

22. Tschernko EM, Wisser W, Wanke T, et al. Changes in ventilatory mechanics and diaphragmatic function after lung volume reduction surgery in patients with COPD. Thorax 1997; 52: 545-550.

23. Rochester DF, Braun NMT. Determinants of maximal inspiratory pressure in chronic obstructive pulmonary disease. Am Rev Respir Dis 1985; 132: 42-47.

24. Arora NS, Rochester DF. Effect of body weight and muscularity on human diaphragm muscle mass, thickness and area. J Appl Physiol: Respirat Environ Exercise Physiol 1982; 52: 64-70.

25. McParland C, Krishnan B, Wang Y, Gallagher CG. Inspiratory muscle weakness and dyspnea in chronic heart failure. Am Rev Respir Dis 1992; 146: 467-472.

26. McParland C, Resch EF, Krishnan B, Wang Y, Cujec B, Gallagher CG. Inspiratory muscle weakness in chronic heart failure: role of nutrition and electrolyte status and systemic myopathy. Am J Respir Crit Care Med 1995; 151: 1101-1107.

27. Juan G, Calverley P, Talamo C, Roussos C. Effect of carbon dioxide on diaphragmatic function in human beings. N Engl J Med 1984; 310: 874-879.

28. Decramer M, Stas K. Corticosteroid-induced myopathy involving respiratory muscles in patients with COPD or asthma. Am Rev Respir Dis 1992; 146: 800-802.

29. Decramer M, Lacquet LM, Fagard R, Rogiers P. Corticosteroids contribute to muscle weakness in chronic airflow obstruction. Am J Respir Crit Care Med 1994; 150: $11-16$

30. Molloy DW, Shingra S, Solven F, Wilson A, McCarthy DS. Hypomagnesemia and respiratory muscle power. Am Rev Respir Dis 1984; 129: 497-498.

31. Aubier M, Murciano D, Lecocguic Y, et al. Effect of hypophosphatemia on diaphragmatic contractility in patients with acute respiratory failure. $N$ Engl $J$ Med 1985; 313: 420-424.

32. Killian KJ, Leblanc P, Martin DH, Summers E, Jones NL, Campbell EJM. Exercise capacity and ventilatory, circulatory, and symptom limitation in patients with chronic airflow limitation. Am Rev Respir Dis 1992; 146: 935-940.

33. Hamilton AL, Killian KJ, Summers E, Jones NL. Muscle strength, symptom intensity and exercise capacity in patients with cardiorespiratory disorders. Am J Respir Crit Care Med 1995; 152: 2021-2031.

34. Simpson K, Killian K, Mc Cartney N, Stubbing DG, Jones NL. Randomised controlled trial of weightlifting exercise in patients with chronic air flow limitation. Thorax 1992; 47: 70-75.

35. Clark CJ, Cochrane L, Mackay E. Low intensity peripheral muscle conditioning improves exercise tolerance and breathlessness in COPD. Eur Respir J 1996; 9: 2590-2596.

36. Reid MB, Haack KE, Franchek KM, Valberg PA, Kobzik L, West MS. Reactive oxygen in skeletal muscle. I. Intracellular oxidant kinetics and fatigue in vitro. J Appl Physiol: Respirat Environ Exercise Physiol 1992; 73: 1797-1804.

37. Reid MB, Shoji T, Moody MR, Entman ML. Reactive oxygen in skeletal muscle II. Extracellular release of free radicals. J Appl Physiol: Respirat Environ Exercise Physiol 1992; 73: 1805-1809.

38. Boczkowski J, Lanone S, Ungereau-Longrois D, Danialou G, Fournier T, Aubier M. Induction of diaphragmatic nitric oxide synthase after endotoxin administration in rats. J Clin Invest 1996; 98: 1550-1559.

39. Sieck GC, Prakash YS. Cross bridge kinetics in respiratory muscles. Eur Respir J 1997; 10: 2147-2158.

40. Gea J. Myosine gene expression in the respiratory muscles. Eur Respir J 1997; 10: (in press).

41. Aubier M. Ca-ATPase regulation in the respiratory muscles and its functional significance. Eur Respir $J$ (in press).

42. Petrof BJ. Respiratory muscles as a target for adenovirus gene therapy. Eur Respir J (in press). 
